\title{
Second trimester serum alpha-fetoprotein level is a significant positive predictor for intrauterine growth restriction in pregnant women with hyperemesis gravidarum
}

\author{
Ikinci trimester serum Alfa-Fetoprotein düzeyi hiperemezis gravidarumu olan gebe \\ kadınlarda intrauterin gelişme geriliği için pozitif bir prediktördür
}

\author{
Enis Özkaya ${ }^{1}$ Evrim Çakır², Mehmet Çınar ${ }^{3}$, Metin Altay³, Orhan Gelişen ${ }^{3}$, Fadıl Karal \\ 'Department of Obstetrics and Gynecology, Dr. Sami Ulus Maternity and Women's Health Teaching and Research \\ Hospital, Ankara, Turkey \\ ${ }^{2}$ Department of Endocrinology and Metabolism, Dışkapı Yildırm Beyazıd Teaching and Research Hospital, Ankara, Turkey \\ ${ }^{3}$ Department of Obstetrics and Gynecology, Etlik Zübeyde Hanim Maternity and Women's Health Teaching and \\ Research Hospital, Ankara, Turkey
}

\section{Abstract}

Objective: The aim of this study was to determine the association between three parameters of second trimester serum secreening and preterm labor and intrauterine growth restriction (IUGR) in patients with hyperemesis gravidarum (HG).

Material and Methods: A prospective study on 429 pregnancies with HG was designed to determine the association between alpha-fetoprotein (AFP), unconjugated estriol (uE3), human chorionic gonadotropin (HCG) and pregnancy prognosis in terms of preterm labor, IUGR and birth weight.

Results: In our study group the mean age of patients was $25.4 \pm 3.8$ years. Mean birth weight was $3180 \pm 555 \mathrm{~g}$. Mean AFP, uE3, hCG levels in the study group were $1.44 \pm 0.65 \mathrm{MoM}, 0.91 \pm 0.38 \mathrm{MoM}, 1.09 \pm 0.64$ MoM, respectively. Twenty nine $(6.8 \%)$ patients delivered before 37 weeks of gestation and $52(12.1 \%)$ patients developed IUGR. Mean MoM values of AFP among patients with preterm labor, IUGR and normal delivery were $1.35 \pm 0.45,1.97 \pm 0.81,1.34 \pm 0.58 \mathrm{MoM}$, respectively $(\mathrm{p}<0.001)$. Mean MoM values of hCG among patients with preterm labor, IUGR and normal delivery were $1.46 \pm 0.90,1.35 \pm 0.89,1 \pm 0.5 \mathrm{MoM}$ respectively $(\mathrm{p}<0.001)$. Mean MoM values of $\mathrm{uE} 3$ among patients with preterm labor, IUGR and normal delivery were $0.75 \pm 0.25,0.80 \pm 0.30$, $0.95 \pm 0.40$ MoM, respectively $(\mathrm{p}=0.003)$. Odds ratio of $\mathrm{AFP}>1.55$ was 3.73 (95\% CI, 1.99-6.98, p<0.001) for IUGR after adjustment for HCG.

Conclusion: Our study suggests that AFP levels of the second trimester screening test higher than $1.55 \mathrm{MoM}$ is significantly associated with IUGR in hyperemesis gravidarum. The second trimester screening test can predict poor outcome in HG.

(J Turkish-German Gynecol Assoc 2011; 12: 220-4)

Key words: Second trimester screening, alpha-fetoprotein, intrauterine growth restriction, preterm labor, hyperemesis gravidarum

Received: 28 July, 2011

\section{Özet}

Amaç: Bu çalışmanın amacı hiperemezis gravidarumu olan hastalarda ikinci trimester taramasında kullanılan üç parametre ile preterm eylem, intrauterin gelişme geriliği arasındaki ilişkiyi belirlemek.

Gereç ve Yöntemler: Bu prospektif çalışma hiperemezis gravidarumu olan 429 gebe üzerinde alfafetoprotein (AFP), unkonjuge estriol (uE3), human koryonik gonadotropin (HCG) ile preterm eylem, intrauterin gelişme geriliği arasındaki ilişkiyi belirlemek amacı ile dizayn edildi.

Bulgular: Çalışma grubunda ortalama yaş $25.4 \pm 3.8$ idi. Ortalama doğum ağırlığı $3180 \pm 555$ g olarak hesaplandı. Ortalama AFP, uE3, HCG düzeyleri sırası ile ortalama $1.44 \pm 0.65 \mathrm{MoM}, 0.91 \pm 0.38 \mathrm{MoM}$, $1.09 \pm 0.64 \mathrm{MoM}$ idi. Yirmidokuz (\%6.8) hasta 37 hafta öncesinde doğurdu ve 52 (\%12.1) hastada gelişme geriliği mevcuttu. Preterm eylem, IUGR ve normal doğum yapan grupta ortalama AFP değerleri sırası ile $1.35 \pm 0.45,1.97 \pm 0.81,1.34 \pm 0.58 \mathrm{MoM}$ idi $(\mathrm{p}<0.001)$. Preterm eylem, IUGR ve normal doğum yapan grupta ortalama HCG değerleri sirasi ile $1.46 \pm 0.90,1.35 \pm 0.89,1 \pm 0.5 \mathrm{MoM}(\mathrm{p}<0.001)$. Preterm eylem, IUGR ve normal doğum yapan grupta ortalama HCG değerleri sırası ile $0.75 \pm 0.25,0.80 \pm 0.30,0.95 \pm 0.40 \mathrm{MoM}(\mathrm{p}=0.003)$. IUGR için HCG ye göre düzeltilmiş AFP $>1.55$ için odds oranı 3.73 (\%95 CI, 1.99-6.98, $\mathrm{p}<0.001$ ) olarak saptandl.

Sonuç: Çalışmamıza göre 1.55 in üstündeki AFP düzeyleri hiperemezis gravidarum hastalarında IUGR için risk faktörüdür. İkinci trimester serum taraması HG de kötü prognozu öngörebilir.

(J Turkish-German Gynecol Assoc 2011; 12: 220-4)

Anahtar kelimeler: İkinci trimester tarama, alfa feto protein, intrauterin gelişme geriliği, preterm doğum, hyperemezis gravidarum

Geliş Tarihi: 28 Temmuz 2011

Kabul Tarihi: 07 Eylül 2011

Address for Correspondence: Enis Özkaya, Demetevler 10. Sok. 63/15 Yenimahalle, Ankara, Turkey

Phone: +905054742459 e.mail: enozkaya1979@gmail.com

(C) Copyright 2011 by the Turkish-German Gynecological Education and Research Foundation - Available online at www.jtgga.org doi:10.5152/jtgga.2011.55 


\section{Content}

Hyperemesis gravidarum is associated with high hCG levels. This study investigated the association between parameters of the second trimester screening test and pregnancy outcome in selected group of pregnancies. A high hCG level was not found to be a predictor for poor outcome of pregnancy, while the AFP level was associated with intrauterine growth restriction, with a cut off value lower than the reported value in normal pregnancies.

\section{Introduction}

A small percentage of women experience a severe form of nausea and vomiting known as hyperemesis gravidarum. Estimates of the incidence of hyperemesis vary from $0.3-1.5 \%$ of all live births. Diagnosis is subjective, but the condition is usually described as intractable vomiting leading to fluid, electrolyte and acid base imbalance, nutritional deficiency and weight loss (1). Hyperemesis gravidarum (HG) is the most common cause of hospitalization in the first half of pregnancy and the second most common cause of antenatal hospitalization during pregnancy. Extreme weight loss is common among women with $\mathrm{HG}$, suggesting that $\mathrm{HG}$ is a form of prolonged starvation in pregnancy and that the long-term effects of this condition on women and their offspring warrant further investigation (2). Measurement of maternal serum alpha fetoprotein (AFP), human chorionic gonadotropin (HCG), and unconjugated estriol (uE3) at the beginning of the second trimester of pregnancy is a well established screening test for trisomies. Association between second trimester screening test parameters and several pregnancy complications have been studied in unselected study populations. Previous studies have described the association of abnormal levels of maternal serum AFP and hCG with a variety of problems and complications of pregnancy, such as preterm delivery, fetal growth retardation, fetal death and severe hypertensive disorders in pregnancy (3-5).

Serum human chorionic gonadotropin (hCG) and estradiol levels are higher in women with hyperemesis gravidarum (HG) than in unaffected pregnant controls (6). Concentrations of hCG that are above or below the normal range are associated with poor pregnancy outcomes. It seems that HG and hCG are related and that nutrient restriction during critical periods of embryonic development may ensure production of hCG at optimal levels, protect placental development, and optimize nutrient partitioning between maternal and fetal tissues (7).

The aim of this study was to determine the association between three parameters of second trimester serum screening and preterm labor (PL) and intrauterine growth restriction (IUGR) in patients with $\mathrm{HG}$.

\section{Material and Method}

Four hundred twenty nine patients with first to second trimester diagnosis of hyperemesis gravidarum who had been followed for their pregnancies in Etlik Zübeyde Hanım Maternity and
Women's Health Teaching and Research Hospital between January 2005 to December 2009 were included in the study. The study was approved by the local ethics committee. Informed consents were obtained from all the participants. Diagnosis of hyperemesis gravidarum was based on intractable vomiting leading to fluid, electrolyte and acid base imbalance, nutritional deficiency and weight loss. All patients had repeat hospitalizations during pregnancy follow up for hyperemesis.

Patients with a history of pregnancy complications (preeclampsia, eclampsia, preterm labor, intrauterine growth restriction etc.) and patients with genetic, structural abnormality, preeclampsia, gestational diabetes, elective cesarean, placental ablation in the present pregnancy were excluded from the study in order to select patients without a risk factor for investigated outcomes. None of the patients had systemic disorders (stomach disease, cholelithiasis, gastroenteritis, chronic gastric disease, multiple pregnancy, etc.). Thyroid function tests were all in normal limits. At the beginning of the second trimester, screening test was performed for each patient between $15^{\text {th }}$ to $19^{\text {th }}$ weeks of gestation. After blood serum AFP levels and hCG levels were calculated using the ELISA method; unconjugated estriol was calculated using RIA method for each patients. Patients with increased risk of trisomy and open spina were not excluded from the study. Patients were followed until delivery at monthly intervals. Complications during pregnancies were recorded. Preterm labor was accepted as spontaneous deliveries before 37 weeks of gestation and IUGR was diagnosed in patients with a neonate birth weight smaller than the $10^{\text {th }}$ percentile of that gestational age. IUGR was also evaluated according to $3^{\text {rd }}$ and $5^{\text {th }}$ percentiles. Preterm infants were evaluated for their birth percentiles in order not to miss any IUGR among them.

\section{Statistical analysis}

Collected data was entered into SPSS version 11. For group comparisons, analysis of variance and posthoc Tukey test was used. $P$ value smaller than 0.05 was accepted as statistically significant. Binary logistic regression was used to calculate odds ratio. Correlation analysis was used to calculate the degree of associations and ROC analysis was performed for cut off calculation. Regression analysis was used to determine associations.

\section{Result}

Means of AFP, hCG, uE3 among groups of complicated and uncomplicated pregnancies and groups divided according to birth weight percentiles:

In our study group mean age of patients was $25.4 \pm 3.8$ years. Mean birth weight was $3180 \pm 555$ g Mean AFP, uE3, hCG levels in the study group were $1.44 \pm 0.65 \mathrm{MoM}, 0.91 \pm 0.38$ MoM, 1.09 \pm 0.64 MoM respectively. Twenty nine (6.8\%) patients delivered before 37 weeks of gestation and fifty two (12.1\%) patients developed IUGR. Mean MoM values of AFP level among patients with preterm labor, IUGR and normal deliveries were $1.35 \pm 0.45,1.97 \pm 0.81,1.34 \pm 0.58$ MoM respectively $(\mathrm{p}<0.001)$.

Mean MoM values of hCG level among patients with preterm labor, IUGR and normal deliveries were $1.46 \pm 0.90,1.35 \pm 0.89$, $1 \pm 0.5$ MoM respectively $(p<0.001)$. 
Table 1. Relationship between AFP-MoM, uE3-MoM, hCG-MoM levels in hyperemesis gravidarum and pregnancy outcomes

\begin{tabular}{|c|c|c|c|c|c|c|}
\hline & \multicolumn{2}{|c|}{ IUGR } & \multirow[t]{3}{*}{ p value } & \multicolumn{2}{|c|}{ Preterm Labor } & \multirow[t]{3}{*}{ p value } \\
\hline & No & Yes & & No & Yes & \\
\hline & $n=377$ & $n=52$ & & $n=400$ & $n=29$ & \\
\hline AFP-MoM & $1.34 \pm 0.50$ & $1.97 \pm 0.81$ & 0.00 & $1.45 \pm 0.67$ & $1.35 \pm 0.45$ & 0.00 \\
\hline uE3-MoM & $0.93 \pm 0.39$ & $0.80 \pm 0.29$ & 0.02 & $0.92 \pm 0.38$ & $0.75 \pm 0.25$ & 0.02 \\
\hline hCG-MoM & $1.05 \pm 0.57$ & $1.35 \pm 0.88$ & 0.02 & $1.06 \pm 0.59$ & $1.46 \pm 0.90$ & 0.00 \\
\hline
\end{tabular}

Mean MoM values of uE3 level among patients with preterm labor, IUGR and normal deliveries were $0.75 \pm 0.25,0.80 \pm 0.30$, $0.95 \pm 0.40 \mathrm{MoM}$, respectively $(\mathrm{p}=0.003)$. Mean ages were similar among groups $(\mathrm{p}=0.189)$. Mean values between pregnancy complications were shown in Table 1.

Mean MoM values of AFP levels among patients with birth weights below $3^{\text {rd }}(n=5,1.2 \%), 3-5^{\text {th }}(n=12,2.8 \%)$ and $5-10^{\text {th }}$ $(n=35,8.1 \%)$ percentiles of that gestational age were $2.66 \pm 0.25$, $1.98 \pm 0.23,1.83 \pm 0.91 \mathrm{MoM}$, respectively $(\mathrm{p}<0.001)$.

Mean MoM values of hCG levels among patients with birthweights below $3^{\text {rd }}, 3-5^{\text {th }}$ and $5-10^{\text {th }}$ percentiles of that gestational age were $3,0.92 \pm 0.84,1.20 \pm 0.61 \mathrm{MoM}$, respectively $(\mathrm{p}<0.001)$. Mean MoM values of uE3 among patients with birth weights below $3^{\text {rd }}, 3-5^{\text {th }}$ and $5-10^{\text {th }}$ percentiles of that gestational age were $0.5,0.86 \pm 0.22,0.82 \pm 0.32 \mathrm{MoM}$, respectively $(\mathrm{p}=0.023)$. Highest AFP $(p<0.001, p=0.012)$ and hCG $(p<0.001)$ levels were seen in patients with newborn birth weights below the $3^{\text {rd }}$ percentile. Mean ages were similar among different birth weight percentile groups $(p=0.141)$.

\section{Correlations}

AFP level was positively correlated with IUGR $(r=0.351$, $\mathrm{p}<0.001)$, negatively correlated with birth weight $(\mathrm{r}=-0.222$, $\mathrm{p}<0.001)$. uE3 level was positively correlated with birth weight $(\mathrm{r}=0.245, \mathrm{p}<0.001)$ and negatively correlated with IUGR $(\mathrm{r}=-0.123, \mathrm{p}=0.023)$ and PL $(\mathrm{r}=-0.122, \mathrm{p}=0.024)$. hCG level was negatively correlated with birth weight $(\mathrm{r}=-0.199, \mathrm{p}<0.001)$ and positively correlated with IUGR $(r=0.167, p=0.002)$ and PL $(\mathrm{r}=0.175, \mathrm{p}=0.001)$.

\section{Associations}

Regression analysis revealed that $\mathrm{UE} 3$, hCG adjusted AFP; AFP, hCG adjusted uE3; uE3, AFP adjusted hCG were significantly associated with birth weight and IUGR $(p<0.001, p<0.001$, $\mathrm{p}<0.05$, respectively, Figure 1). uE3, AFP adjusted hCG was significantly associated with PL $(\mathrm{p}<0.05)$.

Hyperemesis gravidarum was first diagnosed at different gestational ages in the study group: at $9^{\text {th }}$ week $(n=22,5 \%), 10^{\text {th }}$ week $(n=43: 10 \%), 11^{\text {th }}$ week $(n=51,12 \%), 12^{\text {th }}$ week $(n=61,14 \%)$ and $13^{\text {th }}$ week (n:252.59\%).

Gestational age of hyperemesis gravidarum diagnosis was positively correlated with birth weight $(r=0.288, p=0.001)$, negatively correlated with PL $(\mathrm{r}=-0.189, \mathrm{p}=0.001)$ and IUGR $(r=-0.181, p=0.001)$.

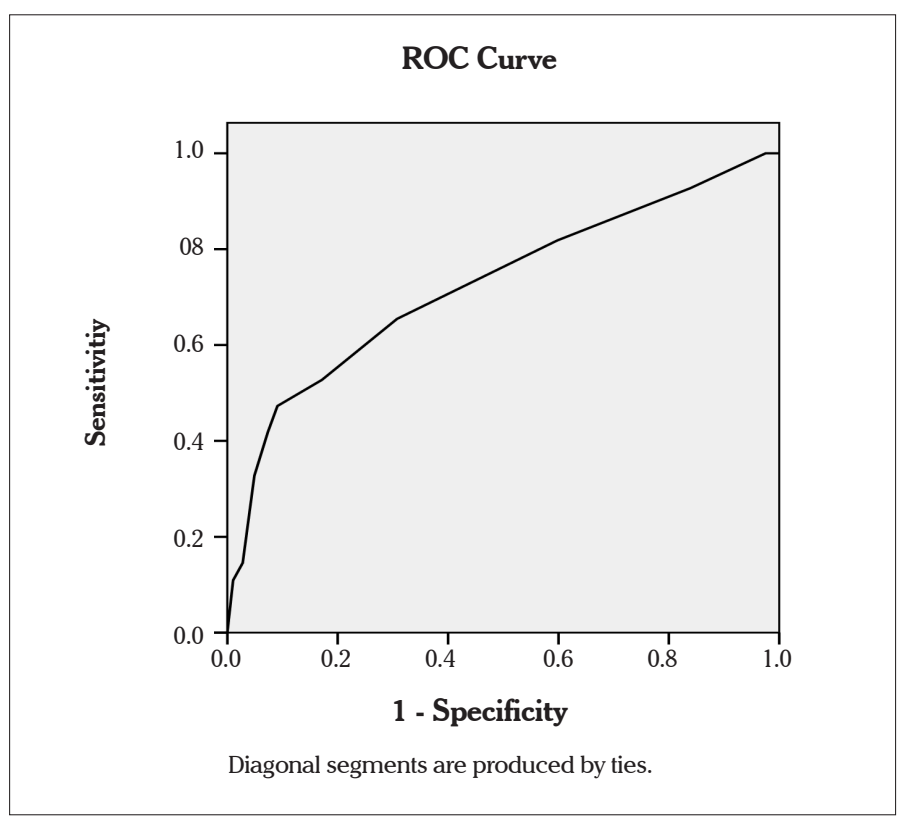

Figure 1. ROC analysis revealed that AFP levels is a significant predictor for IUGR

\section{ROC analysis}

ROC analysis revealed that the AFP level is a significant predictor for IUGR (Area under curve 0.716, p <0.001, Figure 2). Cut off value was $1.55 \mathrm{MoM}$ for the AFP level to predict IUGR with $66 \%$ sensitivity and $69 \%$ specificity. uE3 and hCG levels were not found to be significant predictors for either preterm labor or IUGR in ROC analysis ( $\mathrm{p}>0.005)$.

Odds ratio of AFP>1.55 was 3.73 (95\% CI, 1.99-6.98, p<0.001) for IUGR after adjustment for hCG.

\section{Discussion}

In our study higher AFP levels were found to be significantly associated with increased IUGR while higher hCG levels were shown to be associated with increased preterm labor rates, higher uE3 levels were associated with both decreased preterm labor and IUGR rates. We expected to observe an association between pregnancy complications caused by hyperemesis and increased hCG levels in HG. Association between hCG and uE3 levels with preterm labor and IUGR were shown in regression analysis, however they are not found to be significant predictors for IUGR or preterm labor in ROC analysis. These results led us to hypothesize that the second trimester screening test can give more information about pregnancy outcome in HG, but only the AFP was useful as a test to predict poor outcome. Patients 


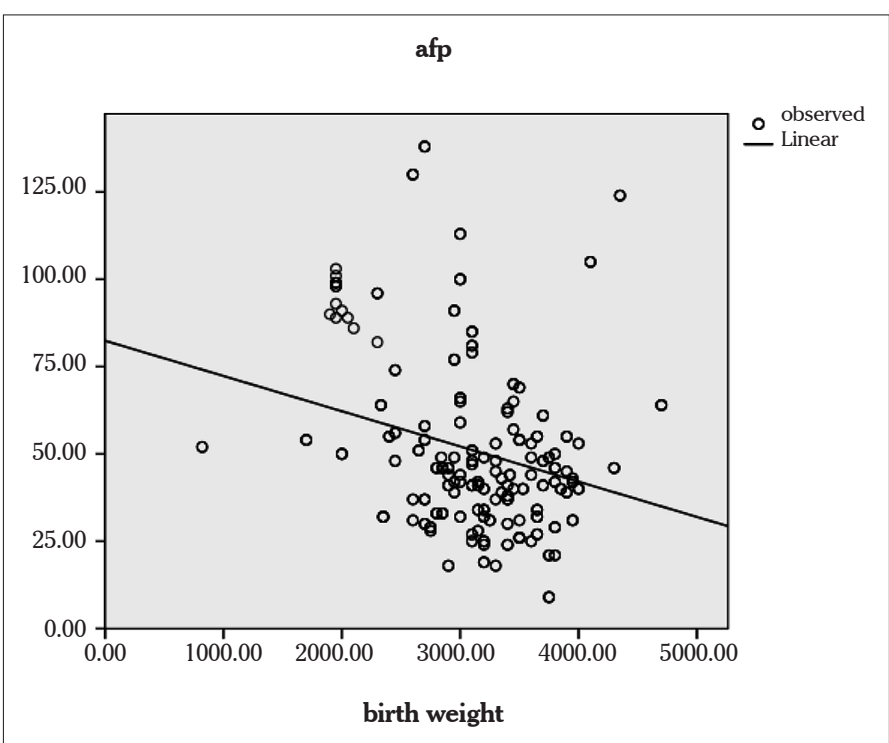

Figure 2. Relationship between AFP levels and birth weight

with different birth weight percentiles in the IUGR group were significantly different in terms of hCG, AFP and uE3 levels. The highest hCG and AFP levels were observed in patients with a birth weight lower than the $3^{\text {rd }}$ percentile. These results are all thought to be due to increased abnormal placental tissue. Our literature search revealed that, while hyperemesis gravidarum has been found to be associated with high hCG levels (6), its effect on second trimester screening, AFP and unconjugated estriol levels in HG has not been studied. Hyperemesis occurs in 473 of 100.000 live births and is associated with significant changes. Infants of mothers with hyperemesis have lower birth weights and the mothers are more likely to have infants that are small for gestational age (8). Although elevated maternal serum AFP level usually shows an elevated risk for neural tube defects, they are also related to adverse pregnancy outcomes such as preeclampsia, spontaneous abortion, preterm delivery, low birth weight, IUGR, oligohydramnios, placental abruption and stillbirth (9-12), all of which are thought to be associated with abnormal placentation (13). In our study, a significant association between serum AFP values and IUGR was observed.

Patients with high AFP levels and bilateral uterine artery diastolic notch presence, were found to be candidates for pregnancy complications and these groups of patients were advised to be followed up more closely (14).

Multiparameter testing of placental function in the mid-trimester (uterine artery Doppler, placental morphology, AFP and hCG screening) may allow us to identify women with increased risk of developing severe placental insufficiency and pregnancy complications (15).

Increased maternal serum AFP $>1.89$ MoM were found to be significantly associated with IUGR, pregnancy induced hypertension (PIH) and placental pathology. In our study group, the cut off value was lower, and this might be due to the presence of hyperemesis with higher hCG levels compared to normal pregnancies. Increased beta-hCG $>1.69 \mathrm{MoM}$ were significantly associated with PIH and IUGR. It was concluded that the triple test can be used not only for the detection of fetal chromosomal and neural tube defect abnormalities but also for the detection of high-risk pregnancies (16).

Recently published data has shown that serum unconjugated estriol, AFP or hCG values in triple test results may be associated with development of oligohydramnios, gestational diabetes and macrosomia in women with healthy and normal appearing fetuses (17).

Despite the increase in prematurity and low birth weight, unexplained raised levels of AFP were not associated with an increase in perinatal mortality (18). A retrospective trial found that increased antenatal surveillance for women with unexplained elevated AFP did not provide any benefit for detection of adverse events (19). Women with elevated second-trimester hCG values have been reported to have increased risks for preeclampsia, IUGR, small for gestational age (SGA) infants, preterm delivery, spontaneous abortion, stillbirth and placental abnormalities (9, 12, 20-22). However, Ashour et al. (23) suggested that the utility of hCG level as a screening test for preeclampsia was limited. Besides, the relationship between obstetric complications and elevated hCG levels was not confirmed in two other studies $(10,24)$. In another study, preterm delivery, preeclampsia and large for gestational age were found to be associated with only hCG levels of $3 \mathrm{MoM}$ and the authors concluded that increased fetal surveillance is not warranted with lower values (25). Consistent with our results, a low uE3 level was suggested as an independent risk factor for adverse pregnancy outcome and is particularly associated with preeclampsia, in conjunction with IUGR, SGA, oligohydramnios, preterm delivery and stillbirth $(9,12,26)$. In a meta-analysis by Morris et al. Down's serum screening analytes were found to have low predictive accuracy for pre-eclampsia and small for gestational age. The study concluded that they may be a useful means of risk assessment or of use in prediction when combined with other tests (27). This study was conducted specifically on patients with HG, and in our literature review we have not encountered a similar study. The relatively small sample size is a limitation of this study.

Our study suggests that the AFP level of the second trimester screening test of higher than $1.55 \mathrm{MoM}$ is significantly associated with IUGR in HG. The highest hCG and AFP levels were seen in patients with birth weight below the $3^{\text {rd }}$ percentile. Further studies are needed to establish the predictors of poor pregnancy outcome in HG.

\section{Conflict of interest}

No conflict of interest was declared by the authors.

\section{References}

1. Sheehan P. Hyperemesis gravidarum--assessment and management. Aust Fam Physician 2007; 36: 698-701.

2. Fejzo MS, Poursharif B, Korst LM, Munch S, MacGibbon KW, Romero R, et al. Symptoms and pregnancy outcomes associated with extreme weight loss among women with hyperemesis gravidarum. J Womens Health (Larchmt) 2009; 18: 1981-7. [CrossRef]

3. Pergament E, Stein AK, Fiddler M, Cho NH, Kupferminc MJ. Adverse pregnancy outcome after a false-positive screen for Down syndrome using multiple markers. Obstet Gynecol 1995; 86: 255-8. [CrossRef] 
4. Morssink LP, de Wolf BT, Kornman LH, Beekhuis JR, van der Hall TP, Mantingh A. The relation between serum markers in the second trimester and placental pathology. A study on extremely small for gestational age fetuses. Br J Obstet Gynaecol 1996; 103: 779-83. [CrossRef]

5. Guven MA, Tanriverdi HA, Kılınç M, Sapmaz K, Usal D, Ademir G. Role of the Second Trimester Maternal Serum AFP Levels in Diagnosing Gestational Diabetes Mellitus, Low Birth Weight and Preterm Labor. J Turkish German Gynecol Assoc 2005; 6: 107-10.

6. Tan PC, Tan NC, Omar SZ. Effect of high levels of human chorionic gonadotropin and estradiol on the severity of hyperemesis gravidarum. Clin Chem Lab Med 2009; 47: 165-71. [CrossRef]

7. Furneaux EC, Langley-Evans AJ, Langley-Evans SC. Nausea and vomiting of pregnancy: endocrine basis and contribution to pregnancy outcome. Obstet Gynecol Surv 2001; 56: 775-82. [CrossRef]

8. Bailit JL. Hyperemesis gravidarium: Epidemiologic findings from a large cohort. Am J Obstet Gynecol 2005; 193: 811-4. [CrossRef]

9. Yaron Y, Cherry M, Kramer RL, O'Brien JE, Hallak M, Johnson MP, et al. Second-trimester maternal serum marker screening: maternal serum alpha-fetoprotein, beta-human chorionic gonadotropin, estriol, and their various combinations as predictors of pregnancy outcome. Am J Obstet Gynecol 1999; 181: 968-74. [CrossRef]

10. Spencer K. Second-trimester prenatal screening for Down syndrome and the relationship of maternal serum biochemical markers to pregnancy complications with adverse outcome. Prenat Diagn 2000; 20: 652-6. [CrossRef]

11. Wenstrom KD, Owen J, Boots LR, DuBard MB. Elevated secondtrimester human chorionic gonadotropin levels in association with poor pregnancy outcome. Am J Obstet Gynecol 1994; 171: 1038-41.

12. Duric K, Skrablin S, Lesin J, Kalafatic D, Kuvacic I, Suchanek E. Second trimester total human chorionic gonadotropin, alphafetoprotein and unconjugated estriol in predicting pregnancy complications other than fetal aneuploidy. Eur J Obstet Gynecol Reprod Biol 2003; 110: 12-5. [CrossRef]

13. Boyd PA. Why might maternal serum AFP be high in pregnancies in which the fetus is normally formed? Br J Obstet Gynaecol 1992; 99: 93-5. [CrossRef]

14. Karsidag AY, Buyukbayrak EE, Kars B, Suyugul U, Unal O, Turan MC. The relationship between unexplained elevated serum markers in triple test, uterine artery Doppler measurements and adverse pregnancy outcome. J Pak Med Assoc 2010; 60: 181-6.

15. Androutsopoulos G, Gkogkos P, Papadopoulos V, Adonakis G, Tsapanos V, Vassilakos P, et al. Mid-trimester maternal serum markers in predicting adverse pregnancy outcome. Clin Exp Obstet Gynecol 2009; 36: 237-40.

16. Bas-Budecka E, Perenc M, Sieroszewski P. Abnormal second trimester screening for fetal chromosomal abnormalities as a predictor of adverse pregnancy outcome. Ginekol Pol 2007; 78: 877-80.
17. Sayin NC, Canda MT, Ahmet N, Arda S, Sut N, Varol FG. The association of triple-marker test results with adverse pregnancy outcomes in low-risk pregnancies with healthy newborns. Arch Gynecol Obstet 2008; 277: 47-53. [CrossRef]

18. Kiran TS, Bethel J, Bhal PS. Correlation of abnormal second trimester maternal serum alpha-fetoprotein (MSAFP) levels and adverse pregnancy outcome. J Obstet Gynaecol 2005; 25: 253-6. [CrossRef]

19. Huerta-Enochian G, Katz V, Erfurth S. The association of abnormal alpha-fetoprotein and adverse pregnancy outcome: does increased fetal surveillance affect pregnancy outcome? Am J Obstet Gynecol 2001; 184: 1549-53. [CrossRef]

20. Waller DK, Lustig LS, Cunningham GC, Feuchtbaum LB, Hook EB. The association between maternal serum alpha-fetoprotein and preterm birth, small for gestational age infants, preeclampsia, and placental complications. Obstet Gynecol 1996; 88: 816-22. [CrossRef]

21. Luckas MJ, Sandland R, Hawe J, Neilson JP, McFadyen IR, Meekins JW. Fetal growth retardation and second trimester maternal serum human chorionic gonadotrophin levels. Placenta 1998; 19: 143-7. [CrossRef]

22. Lepage N, Chitayat D, Kingdom J, Huang T. Association between second-trimester isolated high maternal serum maternal serum human chorionic gonadotropin levels and obstetric complications in singleton and twin pregnancies. Am J Obstet Gynecol 2003; 188: 1354-9. [CrossRef]

23. Ashour AM, Lieberman ES, Haug LE, Repke JT. The value of elevated second-trimester beta-human chorionic gonadotropin in predicting development of preeclampsia. Am J Obstet Gynecol 1997; 176: 438-42. [CrossRef]

24. Walton DL, Norem CT, Schoen EJ, Ray GT, Colby CJ. Secondtrimester serum chorionic gonadotropin concentrations and complications and outcome of pregnancy. N Engl J Med 1999; 341: 2033-8. [CrossRef]

25. Towner D, Gandhi S, El Kady D. Obstetric outcomes in women with elevated maternal serum human chorionic gonadotropin. Am J Obstet Gynecol 2006; 194: 1676-81. [CrossRef]

26. Kowalczyk TD, Cabaniss ML, Cusmano L. Association of low unconjugated estriol in the second trimester and adverse pregnancy outcome. Obstet Gynecol 1998; 91: 396-400. [CrossRef]

27. Morris RK, Cnossen JS, Langejans M, Robson SC, Kleijnen J, Ter Riet G, et al. Serum screening with Down's syndrome markers to predict pre-eclampsia and small for gestational age: systematic review and meta-analysis. BMC Pregnancy Childbirth 2008; 8: 33. [CrossRef] 